\title{
Corporate Social Responsibility of Oil Companies and Host Community's Satisfaction: Case Study of Total Company Block (10) Yemen
}

\author{
Fahmi Shaaban Fararah \\ Seiyun Community College, Hadhramout, Yemen \\ E-mail: kuinfahmi@gmail.com \\ Omar Ali Khateeb \\ Oil and Mineral Office, Hadhramout, Yemen \\ E-mail: omarakhateeb@hotmail.com
}

Received: March 21, 2018 Accepted: April 10, 2018 Published: July 3, 2018

doi:10.5296/ber.v8i3.13355

URL: https://doi.org/10.5296/ber.v8i3.13355

\begin{abstract}
This study aims to investigate the relationship between oil host community and TOTAL Company that operates in block 10 in Sah district in Hadramout governorate, Yemen. Moreover, the study examined the relationship between the philanthropic activities provided by the company and the environmental impact caused by oil operation of the company, and the satisfaction of host communities.

The quantitative research method was used by distributing 270 questionnaires in host communities in Saha district, Hadramout governorate. Furthermore, this research used simple random sample to collect the data and SPSS was used for descriptive analysis and cleaning the data while Partial Least Squares Structural Equation Modeling (PLS-SEM) used to testing the hypothesis.

The results found that the level of host community's satisfaction is low. In addition, it approved that there is a positive relationship between philanthropic activities and the host community's satisfaction. Furthermore, the study revealed there is a negative relationship between the environmental impact caused by the company' operations and the host community's satisfaction. The study recommended that to promote the host community's satisfaction the oil producing company need to concentrate on protecting the environment
\end{abstract}


form oil accidents and offering the charity activities for the resident of host community.

Keywords: Philanthropic activities, Environmental impact, PLS, SMEs, Host community's Satisfaction, Yemen

\section{Introduction}

Community relation is a part of public relations that has appeared from corporate social responsibility (Alabi and Ntukekpo, 2012). It aimed to build a positive environment in the host community so the community can support the company to perform its operations without any obstacles. Moreover, Corporate Community Relations is mutually beneficial business partnerships that improve the company's image among the community's individuals (Ekeocha, 2001). Mutual relations between community and corporation will decrease the level of community conflict and increase Corporation's performance. Therefore, shared understanding between host community and multinational companies build trustful relationship (Manyindo et al, 2013).

\section{Environmental Impact}

Oil exploration and exploitation involve negative environmental effects, such as oil spill and natural gas emissions (Frynas, 2009).Moreover, increasing the pressure of host communities have led the oil producing companies to take more steps towards protecting the environment and developing the area near the oil operations. The oil producing companies have ethical responsibilities to protect their host communities because the oil exploration and production have a negative impact on people lives and their environment (Frynas, 2005). In addition to concentrating on making profitoil companies need to solve social and environmental problems and to provide people with some benefits (Andabai, 2010).

Furthermore, the oil producing companies have been responsible for some problems in host communities. Because of the bad social impact of oil operation, oil companies were more interesting to take care with an environmental and non-environmental issue. In the same way, oil host communities have experienced from operation of oil producing companies such as environmental degradation and oil spill. As a result, these communities have demanded oil multinational companies to spend money and effort in the development of their region (Dandago \& Arugu, 2014). Moreover, Oil producing communities have suffered from oil operation pollution to the degree some scholars claimed that oil wealth has harmed these communities more than have benefited them.

Furthermore, there are many evidences that relate between the oil production activities and environmental pollution. Host communities have been experienced several environmental accidents such as oil spill and gas flaring (Aminuand Abiodun, 2013). Multinational oil companies should response to host communities' demands to mitigate the environmental problems that have been caused by oil operation (Andabai, 2010). Oil spillage and pollution play an important role in the relationship between multinational oil companies and host communities. The environmental impact of oil exploration and exploitation was the problem of oil host community and it has been the biggest challenge facing the multinational companies (Anyim et al., 2012). 


\section{1) Macrothink}

\section{Philanthropic Activities}

The philanthropic responsibility is being a good corporate citizen and participating in programs that assist people welfare (Carroll, 2009). Therefore, Carroll put philanthropic responsibility on the top of his CSR pyramid. Philanthropy is highly relevant to the oil industry. In developing countries where the governments cannot handle the entire social problem, philanthropic activities consider main parts of social responsibility of the oil companies (Frynas, 2009). Philanthropic activities have been a significant element in community and oil companies relations (Ajala, 1993). Therefore, he advised the oil companies to distribute donations to host community to promote the community relations.

\section{Framework and Hypothesis Development}

Based on the literature review discussed in this study, the model proposed for test in this study is presented in the following graph.

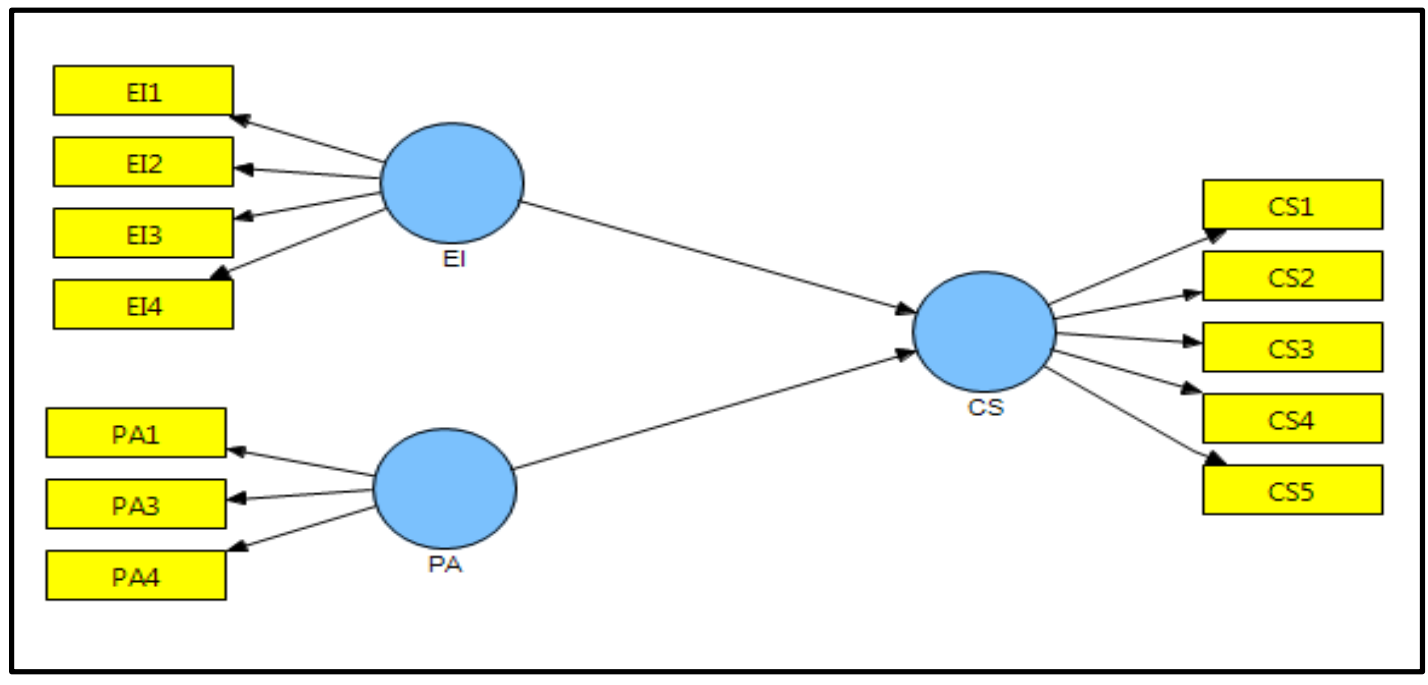

Figure 1. Theoretical Framework

More specifically, in the light of the above framework and reported literature review, this study examined the following hypothesis:

H1: There is a significant negative relationship between Environmental Impact caused by Oil Company and the satisfaction of its host communities.

H2: There is a significant relationship between Philanthropic Activities provided by Oil Company and the satisfaction of its host communities.

\section{Measurements and Instrumentation}

The measurement of host community's satisfaction was derived from previous studies. Specifically, the measurement items employed in this study were taken from (Idemudia, 2009; Alabi \& Ntukekpo, 2012 and Okon et al., 2014). Moreover, the measurements of the environmental impact were derived from the previous studies. Specifically, the measurements employed in this study were taken from (Ganiyu \&Eugene, 2013). The measurements of 
philanthropic activities were adopted from the previous studies. Particularly, the measurements employed in this study were taken from (Ganiyu \& Eugene, 2013).

\section{Population and Sampling}

Since this study examined the effect of environmental impact and philanthropic activities by oil companies of host communities' satisfaction in Yemen. The population of this study consisted of all the residents in five host communities of TOTAL Company. Through a self-administered questionnaire, the data were collected from people who living in (Albelad, Al-Khameera, Gheel Omer, Al-Dhbeaha and Sakdan) in Sah district of Hadramout governorate Yemen. Out of 270 questionnaires distributed, 215 questionnaires were returned and only 210 questionnaires were used for analysis. Moreover, every individual in host community will be a unit of analysis.

\section{Statistical Analysis and Findings}

Before, testing the hypotheses of the study, the measurement model was assessed first using partial least squares structural equation modeling (PLS-SEM). Two steps were followed to know the model's goodness of fit. Firstly, construct validity, which include factor loadings, composite reliability, Cronbach's alpha and convergent validity, was ascertained. Secondly, discriminant validity that includes Fornell-Larcker (1981) criterion was determined. Figure 2 shows the model with its structural dimensions.

\section{A. Construct Validity of the Measurements}

Construct validity refers to the degree to which the items generated to measure a construct can appropriately measure the concept they were designed to measure (Hair et al., 2010). More specifically, all the items designed to measure a construct should load higher on their respective construct than their loadings on other constructs. This was ensured by a comprehensive review of the literature to generate the items that already have been established and tested in previous studies. Based on factor analysis, items were correctly assigned to their constructs. The items showed high loadings on their respective constructs when compared with other constructs as showed in Table 2 and all the items have significantly loaded on their respective constructs.

Table 1. Loading and Cross-Loadings of the items

\begin{tabular}{|c|c|c|c|c|}
\hline Constructs & Items & CS & EI & PA \\
\hline Host Community's Satisfaction & CS1 & $\mathbf{0 . 7 8 3}$ & -0.165 & 0.459 \\
\hline & CS2 & $\mathbf{0 . 7 2 1}$ & -0.104 & 0.342 \\
\hline & CS3 & $\mathbf{0 . 7 0 5}$ & -0.294 & 0.379 \\
\hline & CS4 & $\mathbf{0 . 8 1 9}$ & -0.218 & 0.550 \\
\hline & CS5 & $\mathbf{0 . 7 8 0}$ & -0.200 & 0.474 \\
\hline Environmental Impact & EI1 & -0.121 & $\mathbf{0 . 7 6 1}$ & -0.117 \\
\hline & EI2 & -0.231 & $\mathbf{0 . 8 1 8}$ & -0.235 \\
\hline & EI3 & -0.253 & $\mathbf{0 . 8 6 3}$ & -0.167 \\
\hline & EI4 & -0.200 & $\mathbf{0 . 7 9 8}$ & -0.138 \\
\hline Philanthropic Activities & PA1 & 0.503 & -0.168 & $\mathbf{0 . 8 0 5}$ \\
\hline & PA3 & 0.414 & -0.128 & $\mathbf{0 . 7 5 4}$ \\
\hline & PA4 & 0.462 & -0.194 & $\mathbf{0 . 7 9 1}$ \\
\hline & & & & \\
\hline
\end{tabular}




\section{B. The Convergent Validity}

Table 2 shows that the composite reliability values ranged from 0.827 to 0.885 . These values exceeded the recommended value of 0.7 (Fornell \& Larcker, 1981; Hair et al., 2010). The average variances extracted (AVE) values ranged between 0.582 and 0.658 , indicating a good level of construct validity of the measures used (Barclay et al., 1995). These results confirm the convergent validity of the outer model.

Table 2. Convergent Validity Analysis

\begin{tabular}{|c|c|c|c|c|c|}
\hline Constructs & Items & Loading & Cronbachs Alpha & Composite Reliability & AVE \\
\hline Host Community's Satisfaction & CS1 & $\mathbf{0 . 7 8 3}$ & $\mathbf{0 . 8 2 1}$ & $\mathbf{0 . 8 7 4}$ & $\mathbf{0 . 5 8 2}$ \\
\hline & CS2 & $\mathbf{0 . 7 2 1}$ & & & \\
\hline & CS3 & $\mathbf{0 . 7 0 5}$ & & & \\
\hline & CS4 & $\mathbf{0 . 8 1 9}$ & & & \\
\hline & CS5 & $\mathbf{0 . 7 8 0}$ & & & \\
\hline Environmental Impact & EI1 & $\mathbf{0 . 7 6 1}$ & $\mathbf{0 . 8 3 0}$ & $\mathbf{0 . 8 8 5}$ & $\mathbf{0 . 6 5 8}$ \\
\hline & EI2 & $\mathbf{0 . 8 1 8}$ & & & \\
\hline & EI3 & $\mathbf{0 . 8 6 3}$ & & & \\
\hline & EI4 & $\mathbf{0 . 7 9 8}$ & & & $\mathbf{0 . 6 1 4}$ \\
\hline Philanthropic Activities & PA1 & $\mathbf{0 . 8 0 5}$ & $\mathbf{0 . 6 8 7}$ & & \\
\hline & PA3 & $\mathbf{0 . 7 5 4}$ & & & \\
\hline & PA4 & $\mathbf{0 . 7 9 1}$ & & & \\
\hline
\end{tabular}

a: $\mathrm{CR}=(\Sigma \text { factor loading })^{2} /\left\{(\Sigma \text { factor loading })^{2}\right)+\Sigma$ (variance of error $\left.)\right\}$

$\mathrm{b}: \mathrm{AVE}=\Sigma(\text { factor loading })^{2} /(\Sigma \text { (factor loading })^{2}+\Sigma($ variance of error $\left.)\right\}$

\section{The Discriminate Validity}

The discriminant validity of the measures was confirmed by employing the method of Fornell and Larcker (1981). As illustrated in Table 3, the square root of the average variance extracted (AVE) for all the constructs were placed on the diagonal elements of the correlation matrix. As the diagonal elements were higher than the other elements of the row and column in which they were located, this confirms the discriminant validity of the outer model.

Table 3. Correlations and Discriminate Validity

\begin{tabular}{|l|c|c|c|}
\hline \multicolumn{1}{|c|}{ Constructs } & CS & EI & PA \\
\hline Host Community's Satisfaction & $\mathbf{0 . 7 6 3}$ & & \\
\hline Environmental Impact & -0.261 & $\mathbf{0 . 8 1 1}$ & \\
\hline Philanthropic Activities & 0.589 & -0.210 & $\mathbf{0 . 7 8 4}$ \\
\hline
\end{tabular}

\section{Goodness of fitness}

A comparison was made with the baseline values of $\mathrm{GoF}$ ( small $=0.1$, medium $=0.25$, large $=0.36$ ), as suggested by Wetzels et al. (2009). Table 4 shows that the model's goodness of fit measure was large, indicating an adequate level of global PLS model validity.

Table 4. Goodness of fitness of the items

\begin{tabular}{|l|c|c|}
\hline \multicolumn{1}{|c|}{ Constructs } & AVE & R Square \\
\hline Host Community's Satisfaction & 0.582 & 0.367 \\
\hline Environmental Impact & 0.658 & \\
\hline
\end{tabular}




\begin{tabular}{|l|l|l|}
\hline Philanthropic Activities & 0.614 & \\
\hline Average Gof & 0.618 & 0.367 \\
\hline \multicolumn{1}{|c|}{ Got } & & 0.476 \\
\hline
\end{tabular}

\section{Predictive Relevance of the Model}

Result pertaining to the predictive quality of the model is illustrated in Table 5, which indicated that the cross-validated redundancy of Host Community Satisfaction was 0.031 and the cross-validated communality was 0.582 . These values were more than zero, indicating an adequate predictive validity of the model based on the criteria suggested by Fornell and Cha (1994).

Table 5. Prediction Relevance of the Model

\begin{tabular}{|c|c|c|c|}
\hline Endogenous & R Square & Cross-Validated Redundancy & Cross-Validated Communality \\
\hline Host Community's Satisfaction & 0.367 & 0.031 & 0.582 \\
\hline
\end{tabular}

\section{E. The Structural Model and Hypothesis Testing}

After the construct validity and reliability have been established, the next step was to test the hypotheses of the study by running PLS bootstrapping. The results reported as in Figure 3, and Figure 4.

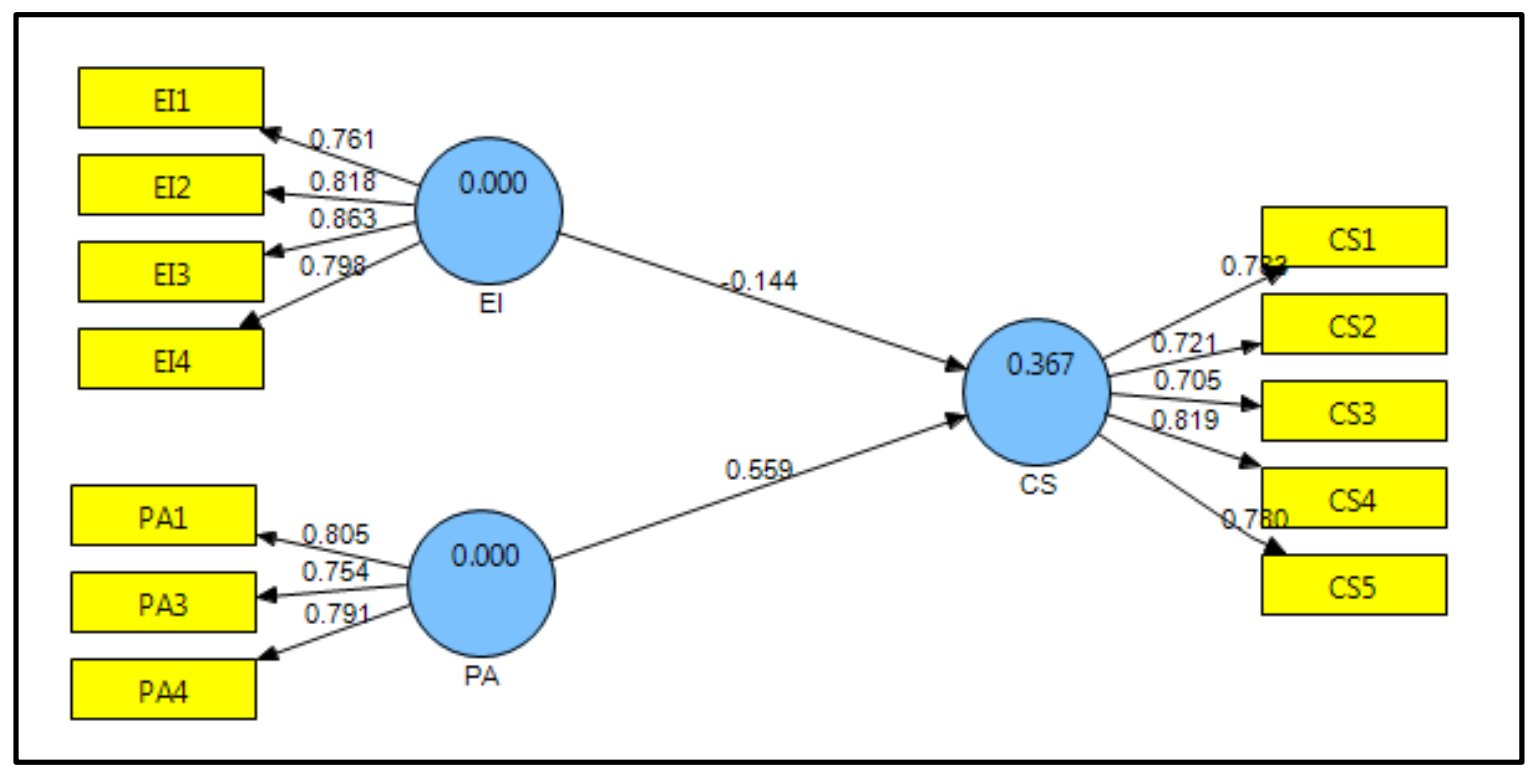

Figure 2. Path Coefficient Results 


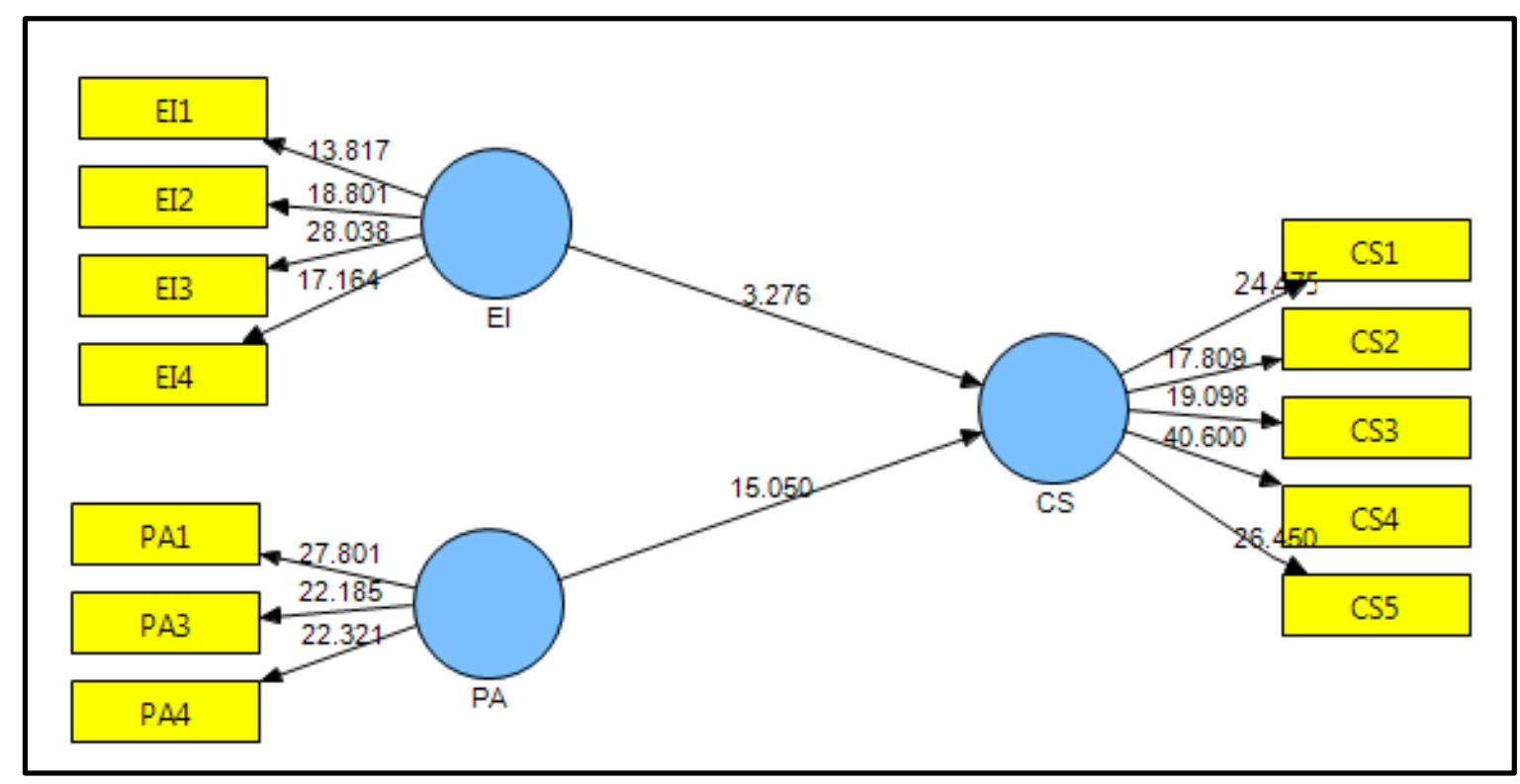

Figure 3. Path Coefficients T values

Table 6. The Results of the Hypothesis Testing

\begin{tabular}{|c|c|c|c|c|c|}
\hline Hypothesis & Path Coefficient & Standard Error (STERR) & T.value & P.value & Decision \\
\hline EI -> CS & -0.144 & 0.044 & 3.276 & 0.001 & Supported \\
\hline PA -> CS & 0.559 & 0.037 & 15.050 & 0.000 & Supported \\
\hline
\end{tabular}

$* * *: p<0.001 ; * *: p<0.01$

As illustrated in Figures 2, 3 and Table 6 environmental impact has a negative and significant effect on the host community satisfaction at the 0.001 level of significance $(\beta=-0.144, t=$ 3.276, $\mathrm{p}>0.001$ ), and Philanthropic activities delivered by the company and the host community's satisfactionhas a positive and significance effectat the 0.01 level of significance $(\beta=0.228, \mathrm{t}=2.417, \mathrm{p}<0.01)$.

\section{Results and Discussion}

The main objective of this study was to examine the effect of oil environmental impact and philanthropic activities of oil companies on the satisfaction of host communities.

According to descriptive analysis in Table 5, the mean of environmental impact (EI) was 4.249 and standard deviation was 0.873. Moreover, the result in Table 6 showed that the relationship between Environmental impact (EI) caused by the oil operation of TOTAL Company and its host community's satisfaction was supported at the 0.01 level of negative and significance effect $(\beta=-0.144, \mathrm{t}=3.276, \mathrm{p}<0.01)$. The study shows that the more environmental accidents caused by the company the more the level of the host community's dissatisfaction towards the oil companies as in line with (Anyim et al., 2012; Idemudia 2009). Therefore, in addition to maximize the corporate social responsibility benefits for community development of host community, the company need to diminish the negative impact of oil exploration and exploitation operations to mitigate the conflict and the dissatisfaction of people in host community. (Anyim et al., 2012; Idemudia, 2009). 
Furthermore, the result in table 6 showed that the relationship between Philanthropic activities delivered by the company and the host community's satisfaction was supported at 0.01 positive significance level $(\beta=0.559, \mathrm{t}=15.050, \mathrm{p}<0.01)$. This result meaning that there is a positive relationship between offered philanthropic activities and host community's satisfaction. The result proves that distributed donations contribute to community's satisfaction and affect in community relation with the company and this in line with (Ajala, 1993). In addition, the study revealed that philanthropic activities are not in host community's priorities and this similar studies (e.g. Alabi \& Ntukekpo, 2012; Okon et al., 2014).

After calculating the mean values made from the respondents, the weighted responses on whether the financial donations have caused the intra community conflict were 2.6, which are above the criterion mean of 2.5 . This result shows that financial donation offered by the company did not produce the conflict between people of host community. In contrast, the previous studies showed that financial donations offered by the company have promoted the intra community conflict. The explanations due to that people are connecting to each other with relative relationships that prevent any dispute.

\section{Conclusions and Recommendations}

Government and the oil producing companies should cooperate by monitoring the impacts of oil exploration and production activities and protect the residents in host community and their environment. Furthermore, oil companies need to work in a transparent manner especially in the environmental issue because the environmental and health impacts of the oil operations are a serious concern in host communities. Yemeni Government should force all the multinational oil companies in to carry out an Environmental Impact Assessment to estimate any inhuman consequences that harm the environment and health of community's residents.

The host community's satisfaction becomes one of the investigated elements in the researches related to the relationship between oil producing companies and their host communities. The satisfaction of the oil host communities has been the concern of all decision-makers in all the developing countries, including Yemen. It has been widely recognized that social responsibility efforts of oil producing companies have been a good factor to improve host community's satisfaction.

The results of this study confirmed the significant direct impact of social responsibility activities such as philanthropic activities by offered by the oil producing companies on the overall satisfaction of host communities. Improving these factors by oil producing companies could be helpful for enhancing the level of oil host community's satisfaction in Yemen. However, the negative effect of the environmental impact on the relationship between host community and oil companies was confirmed.

This study also revealed that, all the oil-producing companies' social efforts should be based on an understanding of the host community needs and expectation to acquire a high level of satisfaction. This implied that the companies should response to the host communities' feedback and grievances. Furthermore, oil-producing companies should managed surveys to measure the host community's level of satisfaction toward the social activities offered by the 
company.

\section{References}

Alabi, O. F., \& Ntukekpo, S. S. (2012). Oil Companies and Corporate Social Responsibility in Nigeria : An Empirical Assessment of Chevron 's Community Development Projects in the Niger Delta. British Journal of Arts and Social Sciences, 4(2), 361-374.

Aminu, Abiodun, S. (2013). The Militancy in the Oil Rich Niger Delta: Failure of the Federa Government of Nigeria. Interdisplinary Journal of Contemporary Research in Business, 4 , 813-827.

Andabai, P. W. (2010). Theoretical Exposition of Conflict Resolution in Nigeria: The Niger Delta Region Experience. African Journal of International Politics and Diplomacy, 1(1and 2), 142-148

Andabai, P. W. (2010). Theoretical Exposition of Conflict Resolution in Nigeria: The Niger Delta Region Experience. African Journal of International Politics and Diplomacy, 1(1and 2), $142-148$

Anyim, F. C., Ikemefuna, O. C., \& Ekwoaba, O. J. (2012). Conflict and Environmental Challenges Facing the Oil Companies in Nigeria Niger-Delta Region. International Journal of Business and Management Tomorrow, 2(3), 1-9.

Barclay, D. W., Thompson, R., \& Higgins, C. (1995). The partial least squares (PLS) approach to causal modeling: personal computer adoption and use an illustration. Technology Studies: Special Issue on Research Methodology, 2(2), 285-309.

Carroll, A. B., \&Buchholtz, A. K. (2009). Business and Society: Ethics and Stakeholder Management, 7th edn. Mason, OH: South-Western Cengage Learning

Dandago, K. I., \&Arugu, L. O. (2014). Corporate Social Responsibility Projects by Transnational Oil Corporations in Nigerian Niger Delta Region: The Experiences of Selected Oil Producing Communities, 2(3), 152-160.

Ekeocha, O. (2001) Conflict and Community Relations Practice in Oil Industry:An SPDC Perspective. Public Relations Journal, 2(2)

Fornell, C., \& Larcker, D. F. (1981). Evaluating structural equation models with unobservable variables and measurement error. Journal of marketing research, 18(1), 39-50.

https://doi.org/10.2307/3151312

Frynas, J. (2009). Corporate social responsibility in the oil and gas sector. The Journal of World Energy Law and Business, 2, 178-195. https://doi.org/10.1093/jwelb/jwp012

Frynas, J. G. (2005). The false development promise of corporate social responsibility: evidence from multinational oil companies. International Affairs, 81(3), 581-598.

https://doi.org/10.1111/j.1468-2346.2005.00470.x

Ganiyu, A., \& Eugene, E. (2013). Relationship between Shell Petroleum Development 
Company (SPDC) and Her Host Communities in the Promotion of Community Development in Rivers State, Nigeria. International Education Research, 21-33.

Hair, J. F., Anderson, R. E., Tatham, R. L., \& Black, W. C. (2010). Multivariate Data Analysis. 7th Ed. Prentice Hall: USA

Idemudia, U. (2009). Assessing corporate-community involvement strategies in the Nigerian oil industry: An empirical analysis. Resources Policy, 34(3), 133-141.

https://doi.org/10.1016/j.resourpol.2009.01.002

Manyindo, J., Parker, R., Van, J., Barihaihi, M., Bazira, H., \& Namande, G. (2013). Seeking Benefits and Avoiding Conflicts: A Community-Company Assessment of Uganda's Hydrocarbon Industry.

Okon, U. E., Ekpo, C. A., Akpan, S. B., Ibok, O. W., \& Bassey, N. E. (2014). Analysis of the Expectations and Benefits of Petroleum Resource Exploration in Oil Producing. International Journal of Management Sciences and Business Research, 3(12), 7-16.

\section{Copyright Disclaimer}

Copyright for this article is retained by the author(s), with first publication rights granted to the journal.

This is an open-access article distributed under the terms and conditions of the Creative Commons Attribution license (http://creativecommons.org/licenses/by/3.0/). 